Volume 1 Nomor 1, Juli-Desember 2017: hlm. 1-10. Magister Ilmu Hukum, Fakultas Hukum, Universitas Lampung, Bandar Lampung, Lampung, Indonesia. E-ISSN: 2598-3105 P-ISSN: 2723-2581 http://jurnal.fh.unila.ac.id/index.php/cepalo

\title{
RESTRUKTURISASI PERJANJIAN KREDIT DALAM PERHATIAN KHUSUS (STUDI KASUS PADA PT BANK RAKYAT INDONESIA, TBK CABANG BANDAR JAYA UNIT HADUYANG RATU)
}

\author{
THE RECONSTRUCTION OF SPECIAL LENDING AGREEMENT ON PT. BANK \\ RAKYAT INDONESIA (PERSERO), TBK, BANDAR JAYA BRANCH, \\ HADUYANG RATU UNIT
}

Ucok Parulianth Simamora

Bank Rakyat Indonesia Cabang Bandar Jaya

liant.simamora@gmail.com

\begin{abstract}
Abstrak
Bank adalah lembaga keuangan terkait pendanaan dan pinjaman. Jika bank memberikan pinjaman yang tidak tepat, hal itu akan menjadi masalah. Oleh karena itu, bank memerlukan hak dan tindakan cepat untuk mencegahnya, serta memberikan pinjaman rekonstruksi. Pertanyaan penelitian ini adalah bagaimana implementasi dan analisis hukum serta konsekuensi dari peminjaman rekonstruksi di PT. Bank Rakyat Indonesia (Persero), Cabang Bandar Jaya, khususnya pada Unit Haduyang Ratu. Penelitian ini menggunakan metode yuridis empiris dan normative, dimana penerapan penelitian melalui studi literatur, dokumentasi dan wawancara. Pemrosesan data melakukan pengeditan, pengkodean, dan analisis. Hasil penelitian menunjukkan bahwa pelaksanaan rekonstruksi pinjaman dalam kasus khusus melalui mediasi dengan debitur, evaluasi dan analisis keputusan pinjaman, dokumentasi dan pengawasan rekonstruksi pinjaman. Pada saat yang sama, analisis pinjaman (kasus pinjaman khusus) harus didasarkan pada Pasal 29 dan Pasal 30 UU 10, 2009 tentang Perbankan dan Pasal 1243, Pasal 1267, dan Pasal 1244 dari Peraturan Sipil Indonesia. Konsekuensi hukum dari rekonstruksi pinjaman dalam kasus khusus adalah pembatalan perjanjian antara PT. Bank Rakyat Indonesia (Persero) dan Emi Rahayuni sebagai Debitur.
\end{abstract}

Kata Kunci: Restrukturisasi Kredit, Perjanjian Kredit Dalam Perhatian Khusus, PT. Bank Rakyat Indonesia, (Persero) Tbk.

\section{Abstract}

Bank is a finance institution which related funding and lending. If bank gives inappropriate lending, it should be trouble. Therefore, bank needs a rights and fast action to prevent it as well as lending reconstruction. The question of research is how to implementation and legal analysis and consequences of lending reconstruction in PT. Bank Rakyat Indonesia (Persero), Bandar Jaya Branch, especially on Haduyang Ratu Unit. Research uses empiricaljudicial method and normative wherein the application of research through literature study, documentation and interview. Data processing does editing, coding, and analysis. The result of research shows that implementation of lending reconstruction in special case pass through mediation with debtor, evaluation and analysis lending decision, documentation and surveillance of lending reconstruction. At the same time, analysis of lending (special lending case) should based on Article 29 and Article 30 of Laws 10, 2009 concerning Banking and Article 1243, Article 1267, and Article 1244 of Indonesia Civil Regulations. Legal consequence of lending reconstruction in special case is a cancel of agreement between PT. Bank Rakyat Indonesia (Persero) and Emi Rahayuni as Debtor. 
Keywords: Lending Reconstruction, Special Lending Agreement, PT. Bank Rakyat Indonesia, (Persero), Tbk.

Cara Mengutip (How to Cite): Ucok Parulianth Simamora, "Restrukturisasi Perjanjian Kredit dalam Perhatian Khusus (Studi Kasus Pada PT Bank Rakyat Indonesia, Tbk Cabang Bandar Jaya Unit Haduyang Ratu)”, Jurnal Cepalo, 1 (1), (2017): 1-10.

DOI: https://doi.org/10.25041/cepalo.v1no1.1750

\section{A. Pendahuluan}

Undang-Undang No 10 Tahun 1998 Tentang Perbankan tepatnya pada Pasal 1 butir 2, menjelaskan pengertian bank sebagai berikut ;"Bank adalah badan usaha yang menghimpun dana dari masyarakat dalam bentuk simpanan dan menyalurkannya kepada masyarakat dalam bentuk kredit dan atau bentuk-bentuk lainnya dalam rangka meningkatkan taraf hidup rakyat banyak". Maksudnya bank merupakan perantara keuangan nasabahnya (financial intermediary) untuk mengolah dana yang didapat dari sekumpulan orang berdana lebih dan menyalurkan dana kepada sekumpulan orang yang membutuhkan dana, dilakukan dalam bentuk kredit yang terbagi dua jenis yaitu kredit produktif dan kredit konsumtif. Hal ini adalah hakikat dari sistem keuangan di setiap negara didunia. ${ }^{1}$ Dalam bahasa latin "credere", "credo", dan. "creditum" yang memiliki arti kepercayaan. Kredit dapat diartikan sebagai perjanjian pinjam meminjam pada kegiatan perbankan. Di Indonesia kredit perbankan diatur didalam Undang-Undang Nomor 10 Tahun 1988. Tepatnya pada Pasal 1 Angka 11 dijelaskan mengenai pengertian kredit, bahwa "kredit ialah bentuk peminjaman uang oleh bank kepada pihak lain sesuai dengan apa yang dituangkan didalam perjanjian yang termasuk kewajiban pihak lain membayar pinjaman tersebut dengan jangka waktu dan penambahan bunga dari bank. ${ }^{2}$

Disebutkan pada Pasal 1 Angka 11 Undang-Undang Nomor 10 Tahun 1998 tentang Perbankan, kegiatan pinjam-meminjam uang yang diklasifikasikan sebagai kegiatan perbankan harus memiliki unsur-unsur sebagai berikut: 1 . Terdapat perjanjian pinjam-meminjam antara bank dan pihak lain; 2. Terdapat sejumlah uang yang dipinjamkan dan jumlah yang ditagihkan; 3. Kewajiban pihak peminjam untuk membayar pinjaman tersebut; 4. Pemberian bunga; 5 . Tenggat waktu yang ditentukan. Bank dianggap sebagai lemabaga yang memiliki peran strategis untuk membangun perekonomian maupun kesuksesan bank tersebut. ${ }^{3}$ Indonesia sebagai Negara yang menganut hukum positif juga diterapkan oleh Perjanjian kredit sebagai contoh perjanjian perikatan. Di KUHPdt ketentuan mengenai perjanjian kredit di atur di Buku III KUHPerdata mengenai Perikatan khususnya pada Pasal 1338 berbunyi "suatu perjanjian sah berlaku sebagai undang-undang bagi pihak yang beranji". Undang-undang khusus perjanjian kredit diatur dalamUndang-UndangNo. 8 Tahun 1999 tentang PerlindunganKonsumen. ${ }^{4}$

Kepercayaan mengenai penyaluran kredit adalah unsur essential maksudnya pihak pemberi pinjaman (kredit) atau yang disebut debitur memberikan kepercayaan kepada penerima pinjaman (kredit) atau yang disebut kreditur, pihak ini dapat memenuhi dan mempertanggung jawabkan atas segala tindakannya sesuai dengan isi perjanjian. ${ }^{5}$ Tetapi tidak dapat disanggah bahwa sengketa akan tetap terjadi dalam proses pelaksanaan isi perikatan, maka, pihak debitur yang ingkar dan enggan melakukan apa yang tertuang di perjanjian disebut wanprestasi. Wanprestasi ini kemungkinan dialami karena beberapa alasan yaitu, pertama akibat terjadinya keadaan yang memaksanya tidak dapat melakukan prestasi (overmacht) dan menjalankan kewajibannya. Atau kedua karena secara sengaja pihak tersebut melakukan wanprestasi. $^{6}$

\footnotetext{
${ }^{1}$ Chatamarrasjid Ais, Hukum Perbankan Nasional Indonesia, Jakarta: Kencana Prenada Media Group, (2007), hlm 7.

${ }^{2}$ M Bahsan, Hukum Jaminan dan Jaminan Kredit Perbankan Indonesia, Jakarta: Rajawali Press, (2012), hlm. 3.

${ }^{3}$ Sutan Remy Syahdeni, Perbankan Islam dan Kedudukannya dalam Tata Hukum Perbankan Indonesia, Jakarta: Pustaka Utama Grafiti, (1999), hlm. 2

${ }^{4}$ M Bahsan, Op.Cit., hlm. 76.

${ }^{5}$ Muhamad Djumhana, Hukum Perbankan di Indonesia, Bandung: Citra Aditya Bhakti, (2000), hlm. 217.

${ }^{6}$ Abdulkadir Muhammad, Hukum Perdata Indonesia, Bandung: Citra Aditya Bakti, (2000), hlm. 203.
} 
Wanprestasi ini harus diselesaikan secara tepat agar tidak berkelanjutan, karena jika tidak menimbulkan kredit bermasalah.

Dalam hal mutu pinjaman (kredit), dapat diklasifikasikan sebagai berikut, yaitu; kredit lancar, kredit dalam perhatian khusus, tidak lancar, meragukan dan kredit macet. ${ }^{7}$ Menurut Surat Edaran Bank Indonesia No 3/10/UPPB pertanggal 12 November 1998 dibagi dua yaitu kredit tidak bermasalah (performing loan) dan kredit bermasalah (non-performing loan). Kredit lancar dan perhatian khusus adalah termasuk dalam jenis kualitas kredit yang tidak bermasalah, perhatian khusus disini maksudnya debitur memiliki kelemahan pada sektor ekonominya ataupun kelayakan kredit debitur. Hal ini tentu perlu perhatian khusus darilembagabank sebagai pemberi kreditur untuk menangani secara khusus karena jenis kualitas kredit ini sangat berpotensi menjadi kredit bermasalah ${ }^{8}$ yang tentunya akan membuat kerugian baik untuk perusahaan atau bahkan kerugian bagi perekonomian negara dikarenakan banyaknya kredit bermasalah. Sedangkan kredit dalam mutu yang tidak lancar, meragukan dan macet termasuk dalam jenis kredit bermasalah.

Kredit bermasalah menimbulkan dampak yang besar seperti yang dijelaskan diatas, maka kredit jenis ini haruslah mendapat penanganan khusus secara tepat dengan dua pilihan opsi, ialah melalui penyelamatan kredit dan melalui penyelesaian kredit. Hal ini dinyatakan didalam Surat Edaran pertanggal 29 Meii Tahun 2993 No 26/4/BPP, disebutkan didalamnya bahwasannya salahsatu opsi dalam menyelamatkan kredit adalah dengan restrukturisasi kredit. Restrukturisasi adalah cara yang diterapkan oleh lembaga bank untuk membantu nasabahnya atau debitur supaya bisa melaksanakan kewajibannya melalui Re-scheduling(penjadwalan ulang),Re-conditioning (Persyaratan ulang) dan Re-structuring (Penataan ulang namun perlu diperhatikan seperti yang disampaikan oleh Siswanto Sutojo bahwa dalam menangani kredit bermasalah pimpinan bank harus tetap pada pedoman pokok penanganan kredit bermasalah seperti penyelamatankredit secara maksimal sebelum ke jalur hukum. ${ }^{9}$

Menurut penelitian ini, restrukturisasi kredit dalam upaya penyelamatan kredit dilakukan juga oleh Perseroan Terbatas Bank Rakyat Indonesia Unit Haduyang Ratu. Kronologisnya adalah tahun 2014 nasabah atas nama Emi Rahayuni mengajukan pinjaman di BRI Unit Haduyang Ratu sebesar Rp.100.000.000 jangka waktu 60 bulan. Pinjaman ini diajukan untuk membiayai usaha jual beli kelapa sawit. Emi Rahayuni merupakan nasabah lama di BRI Haduyang Ratu dan memiliki citra yang baik di bank. Selain itu, usaha yang dijalankan juga sudah lama dan sudah memiliki relasi yang cukup luas. Oleh karena itu, pihak bank merealisasikan pinjaman Emi Rahayuni. Jumlah dana yang direalisasikan sejumlah Rp.100.000.000,- dengan tenggat waktu 60 bulan dengan angsuran tiap bulannya sebesar Rp.2.866.700, pokok pinjaman Rp.1.666.700 dan bunga Rp. 1.200.000, suku bunga 1,2\% flat tiap tahunnya.

Selama dua tahun berjalan, nasabah mengangsur pinjaman dengan lancar, namun, pada pertengahan tahun ketiga nasabah mulai kesulitan membayar angsuran pinjamannya. Setelah berupaya melakukan pemanggilan untuk nasabah disertai pengajuan surat peringatan, melaksanakam penagihan disertai pendekatan khusus dengan debitur selama tiga kali untuk mengetahui kondisi keuangan debitur. Hal ini dikarenakan harga komoditas kelapa sawit yang mengalami penurunan dan banyaknya pesaing di daerah sekitar tempat usaha nasabah. Setelah menganalisis kondisi tersebut, maka pihak bank, dalam hal ini dilakukan oleh pejabat pemrakarsa dan pemutus kredit menawarkan untuk melakukan penyelamatan kredit. Pihak bank memutuskan untuk melakukan penyelamatan kredit karena pihak bank menilai usaha debitur masih layak dan memiliki propek usaha yang baik serta sikap debitur yang kooperatif, artinya masih berusaha untuk membayar angsuran pinjamannya walaupun dalam kondisi keuangan yang kurang baik. Hal ini berdasarkan Peraturan Nomor 14/15/PBI/2012 Tentang Penilaian Kualitas Aset Bank Umum. Sesuai dengan penjelasan diatas, maka dapat ditemukan beberapa permasalahan yang akan dituangkan dalam penelitian ini, antara lain: Bagaimana implementasi

\footnotetext{
${ }^{7}$ Badriyah Harun, Penyelesaian Sengketa Kredit Bermasalah, Jakarta: Suka Buku, (2010), hlm. 115.

${ }^{8}$ Ibid., hlm. 115.

${ }^{9}$ Badriyah Harun. Op.Cit., hlm. 118.
} 
upaya penyelamatan kredit perhatian khusus melalui restrukturisasi perjanjian kredit pada PT Bank Rakyat Indonesia Tbk Cabang Bandar Jaya unit Haduyang Ratu? Dan Bagaimana akibat hukum terhadap restrukturisasi perjanjian kredit dalam perhatian khusus pada PT. Bank Rakyat Indonesia, Tbk. Cabang Bandar Jaya Unit Haduyang Ratu?

Penelitian ini menggunakan metode yuridis empiris dan normatif yang merupakan metode penelitian melalui studi kepustakaan, rangkaian dokumentasi dan wawancara, sedangkan untuk pengolahan data dilakukan dengan editing, coding, dan analisis data. Sumber data yang digunakan yaitu data primer, sekunder dan tersier.

\section{B. Pembahasan}

1. Implementasi Upaya Penyelamatan Kredit Perhatian Khusus Melalui Restrukturisasi Perjanjian Kredit pada PT Bank Rakyat Indonesia Tbk Cabang Bandar Jaya unit HaduyangRatu

Berdasarkan SK Direksi No. S.94-DIR/ADKI12/2005 tanggal 30 Desember 2005 dan SK Direksi No. S.39-DIR/ADKI02/20017 tanggal 14 Februari 2007 Tentang Restruskturisasi Kredit serta Surat Edaran NOSE: S.12-DIR/ADK/5/2013 tentang Restrukturisasi Kredit, maka berdasarkan penelitian yang telah dilakukan, langkah-langkah restrukturisasi kredit yang dilaksanakan oleh PT BRI Tbk Cabang Bandar Jaya, Unit Haduyang Ratu kepada Emi Rahayuni (debitur) ialah:

\section{a. Prakarsa RestrukturisasiKredit}

Pemrakarsa restrukturisasi kredit adalah Mantri dan Kepala Unit BRI Unit Haduyang Ratu. Hal ini sesuai dengan Pasal 4 Surat Edaran NOSE: S.12-DIR/ADK/5/2013 tentang Restrukturisasi Kredit, dimana satuan kerja restrukturisasi kredit pada BRI Unit untuk kategori kredit Performing Loan adalah Kepala Unit dan Mantri.

\section{1) Melakukan Negosiasi denganDebitur}

Pihak BRI Unit Haduyang Ratu, dalam hal ini diwakili oleh Mantri, ia menerapkan cara negoisasi dengan cara menawarkan kebijakan internal bank berupa restrukturisasi kredit kepada debitur dan kabar baiknya hal ini mendapat persetujuan debitur.Dalam Berita Acara Negosiasi dituangkan hasil kesepakatan antara Pihak Pertama yang terdiri dari Kepala Unit dan Mantri dengan pihak kedua, yaitu debitur. Hasil negosiasi antara pihak BRI Unit Haduyang Ratu dengan debitur menghasilkan kesepakatan bahwa kewajiban angsuran debitur tiap bulan adalah Rp.1.848.438 dan jangka waktunya bertambah 60 bulan. Angka ini diperoleh dari kesanggupan debitur untuk membayarangsurannya.

\section{2) Evaluasi dan Analisis RestrukturisasiKredit}

Setelah melakukan kunjungan ke nasabah, maka diketahui apa hambatan yang dimiliki oleh debitur dan mengakibatkan terjadi keterlambatan pembayaran, Hal yang menjadi penyebab kredit bermasalah tersebutadalah:

a) Penurunan Pendapat UsahaDebitur

Usaha debitur mengalami kerugian karena harga sawit yang sangat rendah.

b) BanyaknyaPesaing

Pesaing-pesaing tersebut berani untuk bermain harga sehingga ini sangat merugikan debitur.

Berdasarkan data diatas, upaya restrukturisasi yang diterapkan oleh PT BRI Cabang Bandar Jaya Unit Haduyang Ratu adalah melakukan penjadwalan kembali. Hal ini sesuai dengan isi Surat Edaran No. SES.12-DIR/ADK/5/2013 tentang Restrukturisasi Kredit serta Petunjuk Teknis Restrukturisasi Kredit.

Tabel 1. Data Pinjaman Debitur Dalam Perhatian Khusus Emi Rahayuni BRI Unit Haduyang Ratu 


\begin{tabular}{|c|c|c|c|c|}
\cline { 2 - 5 } Baki Debet & Pokok & Bunga & \multicolumn{1}{c|}{$\begin{array}{c}\text { yang direstruk- } \\
\text { turisasi }\end{array}$} & Jatuh Tempo \\
\hline Rp.59.999.200 & Rp.5.000.100 & Rp.4.481.123 & Rp.64.480.323 & $\begin{array}{l}25-07-2016 \text { s/d } \\
25-07-2021\end{array}$ \\
& & & & \\
\hline
\end{tabular}

Sumber: Data Sekunder, diolah, 2017

Tabel 2. Perubahan BesarAngsuran

\begin{tabular}{|c|c|c|c|c|}
\hline \multirow[b]{2}{*}{ Baki Debet } & \multicolumn{2}{|c|}{ Tunggakan } & \multirow{2}{*}{$\begin{array}{c}\text { Jumlah Pinjaman } \\
\text { yang Direstruk- } \\
\text { turisasi }\end{array}$} & \multirow{2}{*}{$\begin{array}{c}\text { Tgl Realisasi dan } \\
\text { Jatuh Tempo }\end{array}$} \\
\hline & Pokok & Bunga & & \\
\hline Rp.59.999.200 & Rp.5.000.100 & Rp.4.481.123 & Rp.64.480.323 & $\begin{array}{l}25-07-2016 \mathrm{~s} / \mathrm{d} \\
25-07- \\
2021\end{array}$ \\
\hline
\end{tabular}

Sumber: Data Sekunder, diolah, 2017

Tabel 1 menunjukkan data pinjaman debitur dalam perhatian khusus (DPK). Pada tabel tersebut dapat diketahui bahwa jumlah pinjaman yang direstrukturisasi sebesar Rp.64.480.323 yang terdiri dari baki debet Rp.59.999.200, tunggakan pokok Rp.5.000.000 dan tunggakan bunga Rp.4.481.123 dan jangka waktunya bertambah 60 bulan. Tabel 2 menunjukkan perubahan besar angsuran sebelum dan setelah restrukturisasi. Sebelum dilakukan restrukturisasi, angsuran perbulan debitur adalah Rp.2.866.700 dengan angsuran pokok sebesar Rp.1.666.700 dan bunga Rp.1.200.000. Sedangkan kewajiban angsuran yang harus dibayarkan oleh debitur setelah kredit direstrukturisasi lebih kecil dibandingkan dengan sebelum restrukturisasi. Kewajiban angsuran debitur setelah restrukturisasi menjadi Rp.1.848.438 yang terdiri dari angsuran pokok Rp. 1.074.673 dan bunga Rp.773.765. Berdasarkan data tersebut, maka perpanjangan jangka waktu pinjaman (penjadwalan kembali) yang dilakukan oleh pihak BRI Unit Haduyang Ratu diikuti dengan perubahan besar angsuran. Angsuran setelah restrukturisasi lebih kecil dibandingkan dengan sebelum restrukturisasi karena baki debetnya juga lebih kecil dibandingkan sebelum restrukturisasi.

Dari segi implikasi finansial, maka pelaksanaan restruktukrisasi lebih menguntungkan pihak BRI, pertimbangannya adalah: (1) Usaha debitur mengalami penurunan laba, pendapatan usaha digunakan untuk operasional usaha, sementara sumber angsuran kredit adalah dari usaha jual beli sawit; (2) Pengembalian tunggakan pokok kredit yang masih diharapkan adalah sebesar Rp.64.480.323 dengan rincian tunggakan pokok sebesar Rp.59.999.200 dan tunggakan bunga Rp. 4.461.123; (3) Apabila penyelesaian kredit dilakukan melalui Saluran Hukum (DJPLN/Kanwil BUPLN/KP3LN) akan membutuhkan waktu yang tidak sebentar juga biaya yang dibebankan kepada nasabah cukup besar, sehingga dapat mengurangi jumlah pembayaran kredit. Perimbangan atau aspek positif dan negatif yang mendukung pelaksanaan restrukturisasi kredit adalah:

a) AspekPositif

Adanya restrukturisasi kredit, maka akan mengurangi resiko terkena biaya PPAP pada BRI Unit Haduyang Ratu apabila kredit masuk dalam kolektabilitas KL, restrukturisasi dapat memperbaiki kinerja kresit BRI Unit Haduyang Ratu serta dengan adanya penambahan jangka waktu dari pinjaman, diharapkan daya saing usaha debitur meningkat.

b) AspekNegatif

Pokok kredit sebesar Rp. 64.480 .323 dengan perpanjangan jangka waktu pinjaman, maka penerimaan pendapatan dari bunga belum bisa diterima saat realisasi restrukturisasi kredit.

\section{3) Putusan Restrukturisasi Kredit}

Putusan Restrukturisasi Kredit dilakukan oleh pejabat BRI sesuai dengan plafond pinjamannya. Dalam penelitian ini, pemutus kredit adalah Kepala Unit BRI Unit Haduyang 
Ratu, AMBM dan Pemimpin Cabang BRI Cabang Bandar Jaya. Penentuan besar plafond pinjaman restrukturisasi adalah:

Plafond Restrukturisasi $=$ Sisa Pokok $($ Outstanding $)+$ Penambahan Fasilitas Pinjaman/Dana BaruBesaran plafond restrukturisasi agar dibulatkan menjadi angka ribuan guna memudahkan angka nilai angsuran pinjamannya. Sebagai contoh Rp.56.753.682,dibulatkan menjadi Rp.56.750.000,- atau Rp.56.753.000,-. Berdasarkan perumusan tersebut, plafond restrukturisasi debitur Emi Rahayuni adalah Rp.64.480.323.

\section{4) Pengarsipan RestrukturisasiKredit}

Sesuai dengan yang tertuang didalam Kep. Direksi, Surat Edaran NOSE S12DIR/ADK/5/2013 tentang Restrukturisasi Kredit pasal 14, Arsip-arsip yang wajib dimuat pada restrukturisasi kredit ialah:

a) Surat Permohonan oleh Debitur (Emi Rahayuni kepada PT BRI Unit HaduyangRatu).

b) Arsip Laporan Kunjungan Nasabah(LKN)

c) Arsip Berita Acara bahwa telah dilakukan proses negoisasi sebelumnya oleh pihak BRI Unit Haduyang Ratu terhadap Emi Rahayuni untuk menyanggupi pembayaran atashutangnya.

d) Arsip Hasil Penilaian serta Pemeriksaan Agunan pada waktu ini (dokumen foto yang menunjukan kondisi usaha dan/atauagunann)

e) Memorandum Analisis Restruktuirsasi Kredit (MARK) yang dibubuhi tandatangan pejabat berwenang.

Berdasarkan penjelasan diatas, Kepala Unit PT BRI Tbk Cabang Bandar Jaya Unit HaduyangRatu melaksanakan tur lapangan ke rumah debitur untuk mengetahui langsung mengenai kondisi keuangan debitur, yang selanjutnya dibuatlah hasil analisis berdasarkan tur lapangan tersebut dalam MARK oleh mantra.

\section{5) Pengawasan (Monitoring) Restrukturisasi Kredit}

Pengawasan restrukturisasi dilakukan oleh Kepala Unit BRI Haduyang Ratu, AMBM dan Pemimpin Cabang BRI Cabang Bandar Jaya.

\section{Analisis Akibat hukum terhadap restrukturisasi perjanjian kredit dalam perhatian khusus pada PT. Bank Rakyat Indonesia, Tbk. Cabang Bandar Jaya Unit Haduyang Ratu}

Berdasarkan yang tertuang pada Pasal 1313 KUHPdt perjanjian ialah suatu perbuatan dengan mana satu orang atau lebih mengikatkan dirinya terhadap satu orang lain atau lebih berlandaskan teori perjanjian itu sendiri, perjanjian adalah perihal dimana suatu pihak berikrar kepada pihak yang lain dimana keduanya sepakat untuk melakukan segala hal yang telah di sepakati. Maka dari itu, diperlukan perjanjian pokok dan jaminan untuk dijadikan sebagai dasar hukum terjadinya perjanjian kredit.

Berdasarkan konsep tersebut maka dapat disimpulkan bahwa perjanjian akan selalu dilakukan oleh kedua belah pihak, sederhananya pihak satu ialah pihak yang melakukan prestasi dan pihak dua adalah pihak penerima prestasi dari pihak satu. Kedua pihak yang telah menuangkan hal- hal yang telah disepakati menjadi perjanjian, maka perjanjian itu mengikat keduanya seperti undang-undang. ${ }^{10}$ Pernyataan ini sesuai pula dengan yang disebutkan pada Pasal 1338 ayat (1) Kitab Undang-Undang Hukum Perdata, bahwasannya perjanjian sah yang telah dibuat akan dianggap sebagai Undang-Undang untuk para pihak yang telah membuatnya. Lalu, disebutkan bahwa Perjanjin Kredit merupakan bentuk perjanjian pinjam-meminjam yang mana sejalan dengan isi pada Pasal 1774 KUHPdt yang berbunyi: "Perjanjian dengan mana pihak yang satu memberikan kepada pihak yang lain suatu jumlah tertentu barang-barang yang menghabis karena pemakaian, dengan syaratbahwapihak yang belakangan ini akan mengembalikan sejumlah yang sama dari macam dan keadaan yang sama pula."

Hal ini menimbulkan konsekuensi hukum bahwa para pihak wajib melaksanakan

\footnotetext{
${ }^{10}$ Zaeni Asyhadie, 2008, Hukum Bisnis Prinsip dan Pelaksanaannya di Indonesia, Jakarta: Raja Grafindo Persada,
} hlm.8. 
kewajiban sebagaimana tertuang dalam perjanjian tersebut. Jika perjanjian tersebut adalah perjanjian kredit maka debitur wajib melaksanakan pembayaran yang dilakukan secara berkala dengan besaran dan bunga yang sesuai dengan apa yang diperjanjikan. Namun, seiring dengan berjalannya waktu, debitur tidak memenuhi kewajiban sesuai dengan perjanjian, yaitu membayar angsuran kredit sebesar Rp. 2.866 .700 yang terdiri dari angsuran pokok Rp. 1.666.700 danbunga Rp.1.200.000 flat rate, dimana paling lambat pembayaran dilakukan tanggal 15 tiap bulannya. Hal ini menunjukkan bahwa debitur telah melakukan wanprestasi, artinya suatu keadaan yang menunjukkan dimana debitur tidak melaksanakan kewajiban.

Berdasarkan dengankesepakatan yang telah dituangkan dalam perjanjian, Juga debitur terbukti melanggar asas kepercayaan yang telah ada diantara kedua belah pihak sebelum melaksanakan perjanjian.Wanprestasi debitur membawa akibat hukum berupa timbulnya hak kreditur sebagai orang yang telah menderita kerugian untuk menuntut debiturdalam penggantian kerugian. Akibat hukum tersebut diatur pada Pasal 1243 Pasal 1252 KUHPerdata, dimana dasar hukumnya terdapat pada Pasal 1243 KUHPerdata yaitu:

"Penggantian biaya, rugi dan bunga karena tidak dipenuhinya suatu perikatan, barulah mulai diwajibkan, apabila si berutang, setelah dinyatakan lalai memenuhi perikatannya, tetap melalaikannya, atau jika sesuatu yang harus diberikan atau dibuatnya, hanya dapat diberikan atau dibuat dalam tenggang waktu yang telahdilampauinya"

Pihak kreditur, yaitu pihak bank sebagai pihak yang dirugikan akibat wanprestasi yang dilakukan oleh debitur dapat menuntut haknya sebagaimana yang terdapat pada Pasal 1267KUHPerdata berbunyi:

"Pihak yang terhadapnya perikatan tidak dipenuhi, dapat memilih, memaksa pihak lain untuk memenuhi Perjanjian, jika hal itu masih dapat dilakukan atau menuntut pembatalan persetujuan, dengan penggantian biaya, kerugian danbunga."

Penyelesaian kredit bermasalah akibat wanprestasi ini dapat dilakukan melalui 2 opsi, yaitu melalui penyelamatan kredit dan penyelesaian kredit. Namun, dalam pelaksanannya, negosiasi menjadi hal yang pertama diupayakan oleh bank sebelum membawa permasalahan tersebut ke pengadilan. Wanprestasi merupakan perbuatan hukum dalam rangka mengklaim kerugian atas dirinya yang disebabkan oleh pihak lain dalam perjanjian. Maka sesuai dengan ketentuan pada Pasal 1365 KUHPdt dinyatakan bahwa pihak yang mengakibatkan kerugian tersebut wajib mangganti segala kerugian kepada pihak yang dirugikan. Sesudah melakukan analisis terhadap usaha debitur, menilai kepribadian debitur, dan mempertimbangkan berbagai aspek, maka keputusan untuk merestrukturisasi kredit dalam perhatian khusus (DPK) atas namaEmi Rahayuni adalah langkah yang palingtepat. ${ }^{11}$

Keputusan untuk melakukan restrukturisasi kredit debitur Emi Rahayuni sesuai dengan Teori Utilitarisme (Kemanfaatan). Teori ini Menjelaskan tentang tata cara serta pertimbangan dalam pengambilan keputusan yang menyangkut kepentingan umum. Secara normatif, Upaya Penyelamatan Kredit melalui restrukturisasi hanya dapat diterapkan kepada debitur yang mengalami kesulitan dalam membayar angsuran bukan kepada debitur yang dengan sengaja tidak membayar karena itikad yang tidak baik. ${ }^{12} \mathrm{Hal}$ ini diatur dalam Pasal 1244 Kitab Undangundang Hukum Perdata, yaitu:

"Jika ada alasan untuk itu, si berhutang harus dihukum mengganti biaya, rugi dan bunga, apabila ia tidak dapat membuktikan bahwa hal tidak dilaksanakan atau tidak pada waktu yang tepat dilaksanakannya perjanjian itu, pun tidak dapat dipertanggungjawabkan padanya, kesemuanya itupun jika itikad buruk tidaklah ada pada pihaknya” Berdasarkan Pasal 1244 KUHPerdata tersebut, maka debitur yang dengan sengaja tidak membayar kewajibannya kepada kreditur, walaupun memiliki kemampuan untuk membayarnya wajib dikenai hukuman untuk membayar biaya, rugi dan bunga kepada kreditur. Pelaksanaan restrukturisasi kredit menimbulkan tanggung jawab bank selaku kreditur. Seluruh upaya restrukturisasi yang dilaksanakan oleh lembaga bank wajib dilaporkan kepada Bank Indonesia sesuai dengan peraturan mengenai Laporan Berkala Bank Umum. Sesuai dengan hal tersebut PT BRI Tbk

\footnotetext{
${ }^{11}$ Rudi Darmawan (Wawancara), Kepala Unit BRI Unit Haduyang Ratu. Tanggal 15 Maret 2017.

${ }^{12}$ Hengki Opusunggu (wawancara). Legal Officer BRI Kanwil Lampung tanggal 25 Februari 2017.
} 
Cabang Bandar Jaya Unit Haduyang Ratu mempunyai tanggung jawab yang diatur dalam Pasal 30 Undang-Undang Nomor 10 Tahun 1998 tentang Perbankan. Tanggung jawab untuk melaporkan restrukturisasi kredit oleh Bank kepada Bank Indonesia terkait dengan tanggung jawab Bank Indonesia dalam melakukan pengawasan dan pembinanaan terhadap pelaksanaan restrukturisasi kredit. Hal ini juga tertuang dalam Pasal 29 Undang-Undang Nomor 10 Tahun 1998 tentang Perbankan.

Akibat hukum pelaksanaan restrukturisasi perjanjian kredit dalam perhatian khusus adalah timbulnya konsekuensi batalnya perikatan kredit yang telah memenuhi kata sepakat, dan membatalkan segala hak dan kewajiban bagi BRI Unit Haduyang Ratu selaku kreditur dan Emi Rahayuni selaku debitur. Selain itu, jaminan yang telah diikat Hak Tanggungan memiliki akibat hukum tersendiri. Bagi debitur, konsekuensinya adalah adanya Klausa negatif (negative covenant) yang termasuk dalam pengikatan Hak Tanggungan. Klausa ini mewajibkan debitur untuk tidak melaksanakan tindakan hukum dalam bentuk apapun sebagai jaminan tambahan. Maksud dari tidak melaksanakan tindakan hukum adalah tidak memgalihkan, menyewakan bahkan menjual agunan tanpa izin dari kreditur. Bagi kreditur, pengikatan jaminan ini memberikan akibat hukum kepada bank sebagai pihak yang menguasai jaminan, sehingga bank menjadi kreditur preferent Akibat hukum ini menguntungkan BRI Unit Haduyang Ratu, Karena debitur Emi Rahayuni akan memberikan uang pelunasan yang ia dapatkan melalui lelang-eksekusi jaminan berdasarkan besaran jumlah uang yang dihutangkan kepada kreditur secara penuh. Pelunasan ini tentu sifatnya diutamakan karena adanya peristiwawan prestasi

\section{Penutup}

Maka berdasarkan pemaparan diatas, di tarik kesimpulan sebagai berikut:

1. Dalam melakukan upaya penyelamatan kredit melalui restrukturisasi perjanjian kredit dalam perhatian khusus, PT BRI Tbk Cabang Bandar Jaya Unit Haduyang Ratu dilaksanakan dalam beberapa langkah yaitu:

a. Prakarsa Restrukturisasi Kredit; Pemrakarsa restrukturisasi kredit adalah Mantri dan Kepala Unit BRI Unit Haduyang Ratu.

b. Negosiasi dengan Debitur; Negosiasi dilakukan oleh mantri atas permohonan restrukturisasi oleh debitur, kemudian mantri melakukan OTS (On the Spot) dan membuat Lembar Kunjungan Nasabah (LKN) serta Berita Acara Negosiasi (BAN).

c. Evaluasi dan Analisis; Hasil evaluasi menunjukkan bahwa permasalahan yang dihadapi debitur adalah penurunan harga komoditas kelapa sawit dan banyaknya pesaing sehingga debitur mengalami kesulitan dalam pembayaran kewajibanya kepada BRIUnit Haduyang Ratu. Restrukturisasi yang dilakukan adalah dengan perpanjangan jangka waktu pinjaman (penjadwalan kembali) diikuti dengan perubahan besarangsuran.

d. Putusan Restrukturisasi Kredit; Pemutus kredit adalah Kepala Unit BRI Unit Haduyang Ratu, AMBM dan Pemimpin Cabang BRI Cabang BandarJaya.

e. Dokumentasi Restrukturisasi Kredit; Dokumentasi Restrukturisasi Kredit terdiri dari Surat Permohonan Debitur, LKN, BAN, Hasil Pemeriksaan, Penilaian Agunan saat ini serta foto usaha dan Agunan, Memorandum Analisis Restrukturisasi Kredit (MARK) Dan harus ditandatangani secara sah oleh pejabat pelopor restrukturisasi kredit

f. Pengawasan Restrukturisasi Kredit; Pengawasan restrukturisasi dilakukan oleh Kepala Unit BRI Haduyang Ratu, AMBM dan Pemimpin Cabang BRI Cabang Bandar Jaya.

2. Upaya penyelamatan kredit melalui Restrukturisasi perjanjian kredit dalam perjanjian khusus PT BRI Tbk Cabang Bandar Jaya Unit Haduyang Ratu dianalisis berdasarkam dari ketentuan-ketentuan pada Pasal 29 dan Pasal 30 Undang Undang Nomor 10 Tahun 1998 tentang Perbankan serta Pasal 1243, Pasal 1267, Pasal 1244 KUHPerdata.

3. Penerapan dan implikasi upaya penyelamatan kredit melalui restrukturisasi perjanjian kredit dalam perhatian khusus memiliki akibat hukum yaitu berupa pembatalan perjanjian awal kredit sesuai kesepakatan dan disertai pembebasan hak dan kewajiban bagi BRI Unit Haduyang Ratu selaku kreditur dan Emi Rahayuni selaku debitur. Selain itu, jaminan yang telah diikat Hak Tanggungan memiliki akibat hukum, bagi debitur adalah adanya negative covenant (klausa negatif) sedangkan bagi kreditur, bank menjadi kreditur preferent. 


\section{A. Buku}

\section{DAFTAR PUSTAKA}

Ais, Chatamarrasjid. (2007). Hukum Perbankan Nasional Indonesia. Jakarta: Kencana Prenada Media Group.

Asikin, Zainal dan Amirudin. (2012). Pengantar Metode Penelitian Hukum. Jakarta: Radja Grafindo Persada.

Asyhadie, Zaeni. (2008). Hukum Bisnis Prinsip dan Pelaksanaannya di Indonesia. Jakarta: RajaGrafindoPersada.

Bahsan, M. (2012). Hukum Jaminan dan Jaminan Kredit Perbankan Indonesia. Jakarta: Rajawali Press.

Djumhana, Muhamad. (2000). Hukum Perbankan di Indonesia. Bandung: Citra Aditya Bhakti.

Harun, Badriyah. (2010). Penyelesaian Sengketa Kredit Bermasalah. Jakarta: Suka Buku.

Muhammad, Abdulkadir. (2010). Hukum Perusahaan Indonesia. Bandung: Citra Aditya.

Syahdeni, Sutan Remy. (1999). Perbankan Islam dan Kedudukannya dalam Tata HukumPerbankan Indonesia. Jakarta: Pustaka Utama Grafiti Pressindo.

\section{B. Peraturan Perundang-Undangan dan Surat Keputusan}

Kitab Undang-Undang Hukum Perdata (KUHPerdata).

Peraturan Bank Indonesia No:7/2/PBI/2005 Tentang Penilaian Kualitas Aktiva Bank Umum Peraturan Bank Indonesia Nomor 15/2/PBI/2013 tentang Penetapan Status dan Tindak LanjutPengawasan Bank Umum Konvensional.

Peraturan Bank Indonesia Nomor 5/8/PBI/2003 tentang Manajemen Risiko Bagi Bank Umum. Petunjuk Teknis Restrukturisasi Kredit. PT. Bank Rakyat Indonesia (Persero), Tbk.

Surat Keputusan Direksi Bank Indonesia Nomor: 31/177/KEP/DIR tentang Batas Maksimum Pemberian Kredit Bank Umum.

Surat Edaran Bank Indonesia Nomor 7/190/DPNP/IDPnP tanggal 26 April 2005, dan Surat Edaran Bank Indonesia Nomor 7/319/ DPNP/IDPnP tanggal 27 Juni 2005 tentang Kebijakan RestrukturisasiKredit.

Surat Edaran No.15/28/DPNP kepada Semua Bank Umum yang Melaksanakan Kegiatan Usaha Secara Konvensional di Indonesia.

Undang-Undang Nomor 7 tahun 1992 tentang Perbankan jo Undang-Undang Nomor 10 tahun 1998 tentang Perubahan Undang-Undang Nomor 7 tahun 1992 tentang Perbankan.

Undang-Undang Nomor 23 tahun 1999 tentang Bank Indonesia. 
